\title{
Postpartum septic pelvic thrombophlebitis and ovarian vein thrombosis after caesarean section: a rare case report
}

\author{
Qin Shi ${ }^{1 \dagger}$, Deborah Shulamite Gandi ${ }^{1 \dagger}$, Yurong Hua ${ }^{2}$, Yi Zhu ${ }^{2}$, Jinhan Yao ${ }^{1}$, Xiaoqing Yang ${ }^{1}$, Yunzhao Xu ${ }^{1}$ and \\ Yuquan Zhang ${ }^{1 *}$
}

\begin{abstract}
Background: Septic pelvic thrombophlebitis (SPT) is a well-recognized but rare puerperal complication that has two types: ovarian vein thrombophlebitis (OVT) and deep septic pelvic thrombophlebitis (DSPT). The present case report describes the clinical and imaging findings of a female patient diagnosed with right ovarian vein infectious thrombophlebitis after caesarean section (C-section).

Case presentation: A 35-year-old G3P2 female who presented with a foetal vein Galen malformation at 41 weeks of gestation underwent C-section. The patient had high fever after C-section, and anti-inflammatory treatment was not effective within 1 week. An abdominal wall incision haematoma was found, and a second surgery for the removal of the abdominal wall haematoma was performed. The patient was ultimately diagnosed with abdominal incision haematoma and right ovarian vein infectious thrombophlebitis after C-section. We used imipenem and tigecycline to strengthen the anti-inflammatory effects, simultaneously administrating low-molecular-weight heparin and warfarin as anticoagulant therapy. On the 30th day after C-section, the right ovarian vein thrombus disappeared.

Conclusion: This case illustrates the need to consider the potential relationship between abdominal incision haematoma and ovarian vein thrombophlebitis. Despite advances in the management of venous thromboembolism globally, more data on epidemiology in terms of first incidence, prevalence, recurrence and risk factors, management of bleeding complications, and increased awareness in Asian populations are necessary.
\end{abstract}

Keywords: Septic pelvic thrombophlebitis, Ovarian vein thrombosis, Caesarean section, Case report

\section{Background}

Septic pelvic thrombophlebitis (SPT) is a wellrecognized but rare puerperal complication (approximately 1 in 3000 deliveries). It occurs more frequently after caesarean section (C-section) (1 in 800 cases) than after vaginal delivery ( 1 in 9000 cases), probably due to the higher rate of puerperal infection $[1,2]$. This

\footnotetext{
* Correspondence: jsnt_zhangyuquan@163.com

${ }^{\dagger}$ Qin Shi and Deborah Shulamite Gandi contributed equally to this work. 'Department of Obstetrics and Gynecology, Affiliated Hospital of Nantong University, Nantong, People's Republic of China

Full list of author information is available at the end of the article
}

complication was quite prevalent previously; its management was almost solely based on surgical treatment, and it was associated with high mortality rates. Recently, the prognosis of SPT has improved, but it can still cause life-threatening conditions [3]. There are two types of SPT: ovarian vein thrombophlebitis (OVT) and deep septic pelvic thrombophlebitis (DSPT). Although these types may differ in clinical presentation and diagnostic findings, they have common pathogenic mechanisms and often occur together. SPT is an important differential diagnosis of abdominal pain and fever in the

C C The Author(s). 2021 Open Access This article is licensed under a Creative Commons Attribution 4.0 International License, which permits use, sharing, adaptation, distribution and reproduction in any medium or format, as long as you give appropriate credit to the original author(s) and the source, provide a link to the Creative Commons licence, and indicate if changes were made. The images or other third party material in this article are included in the article's Creative Commons licence, unless indicated otherwise in a credit line to the material. If material is not included in the article's Creative Commons licence and your intended use is not permitted by statutory regulation or exceeds the permitted use, you will need to obtain permission directly from the copyright holder. To view a copy of this licence, visit http://creativecommons.org/licenses/by/4.0/ The Creative Commons Public Domain Dedication waiver (http://creativecommons.org/publicdomain/zero/1.0/) applies to the data made available in this article, unless otherwise stated in a credit line to the data. 
postpartum period, and its diagnosis might be challenging. The present case report describes the clinical and imaging findings of a female patient diagnosed with right ovarian vein infectious thrombophlebitis after $\mathrm{C}$-section.

\section{Case presentation}

A 35-year-old G3P2 female presented with a LOA (left occipital anterior) foetal position at 41 weeks of gestation. In 2001, she underwent an appendectomy. In 2001, she underwent an appendectomy. In 2008, she delivered a male newborn with a birthweight of $3500 \mathrm{~g}$. In 2010, she underwent a medical abortion during early pregnancy. Prior to this pregnancy, both gynaecological examination and transvaginal ultrasonography were negative. Her menstrual cycle was regular. Her pregnancy at this time was complicated by a large foetus size and abnormal foetal movements, as detected by ultrasound examination, which suggested a Vein of Galen malformation. She was admitted with a blood pressure of 106/70 $\mathrm{mmHg}$, and she denied headache, abdominal pain, or oedema. Reflexes were normal. Her height was $168 \mathrm{~cm}$, her weight was $72 \mathrm{~kg}$, and her body mass index (BMI) was $25.5 \mathrm{~kg} / \mathrm{m}^{2}$. Her haemoglobin level was $130 \mathrm{~g} /$ L. The patient was delivered by caesarean section on the second day with intraoperative blood loss of $350 \mathrm{ml}$. We delivered a male newborn with a birthweight of $4600 \mathrm{~g}$ and an APGAR score of 10/10/10.

On postoperative day 1 , the patient complained of the surgical wound being painful but bearable. Physical examination showed normal body temperature with dry and odourless petechial haemorrhage on the skin surrounding the abdominal incision above the uterine margin and below the navel. The white blood cell (WBC) count was $10.20 \times 10^{9} / \mathrm{L}$, the haemoglobin level was $97 \mathrm{~g} / \mathrm{L}$, and the platelet count level was $79 \times 10^{9} / \mathrm{L}$. On postoperative day 2 , she complained of aggravated pain at the abdominal incision and odourless ecchymosis of the skin around the abdominal incision at the right lateral margin with local tension. The body temperature was $37.5^{\circ} \mathrm{C}$, the WBC count was $11.32 \times 10^{9} / \mathrm{L}$, the haemoglobin level was $88 \mathrm{~g} / \mathrm{L}$, and the platelet count level was $85 \times 10^{9} / \mathrm{L}$. A palpable mass with unclear boundary and tenderness was detected. On postoperative day 3 , the pain of the patient's incision progressively aggravated, with a body temperature of $38.2^{\circ} \mathrm{C}$. An ultrasound examination revealed an abdominal wall incision haematoma with a size of approximately $43 \times 32 \times 10 \mathrm{~mm}$. The WBC count was $9.05 \times 10^{9} / \mathrm{L}$. The haemoglobin level was $83 \mathrm{~g} / \mathrm{L}$, and the platelet count was $88 \times 10^{9} / \mathrm{L}$.

After 1-3 days of C-section, the patient's haemoglobin level showed a progressive decline from 97 to 88 to $83 \mathrm{~g} /$ L. The platelet count had increased from 79 to $88 \times 10^{9} /$ L. B-ultrasound imaging suggested abdominal wall incision haematoma. Based on the abovementioned findings, we considered the diagnosis of abdominal incision haematoma after $\mathrm{C}$-section. A second surgery for the removal of the abdominal wall haematoma was performed on the third day after C-section. We removed a blood clot of approximately $100 \mathrm{ml}$ between the rectus abdominis and the anterior sheath. Moreover, approximately $10 \mathrm{ml}$ of blood clot was removed from the right rear of the rectus abdominis, peritoneal front. The intraoperative blood loss was approximately $20 \mathrm{ml}$. On postoperative day 1 of the second surgery, the patient recorded a body temperature of $39.5^{\circ} \mathrm{C}$, low haemoglobin level of $89 \mathrm{~g} / \mathrm{L}$, and increased platelet count of $108 \times 10^{9} / \mathrm{L}$. The patient was administered piperacillin tazobactam at $2.5 \mathrm{~g}$ $\mathrm{q} 8 \mathrm{~h}$ and levofloxacin at $0.4 \mathrm{~g} \mathrm{q} \mathrm{d}$. Acetaminophen was also administered as an antipyretic symptomatic treatment. The patient was also informed to get out of bed as early as possible and move more frequently to prevent thrombosis. On postoperative day 2 of the second surgery, the body temperature was $38.6^{\circ} \mathrm{C}$, the haemoglobin level was $83 \mathrm{~g} / \mathrm{L}$ and the platelet count increased to $138 \times 10^{9} / \mathrm{L}$. On postoperative day 3 , the body temperature declined to $37.2{ }^{\circ} \mathrm{C}$. On postoperative day 4 of the second surgery, the haemoglobin level was $84 \mathrm{~g} / \mathrm{L}$, and the platelet count level was $167 \times 10^{9} / \mathrm{L}$. Her fibrinogen level was $2.24 \mathrm{~g} / \mathrm{L}$, and her D-dimer level was 6.48 $\mathrm{mg} / \mathrm{L}$, which suggested thrombosis. A computed tomography $(\mathrm{CT})$ scan confirmed the diagnosis of right OVT, with a size of approximately $1 \times 15 \mathrm{~cm}$ (Fig. 1). The patient was then placed on imipenem and tigecycline therapy to strengthen the anti-inflammatory response, with simultaneous administration of low-molecular-weight heparin and warfarin as an anticoagulant therapy. The timeline from diagnosis to treatment is shown in Fig. 2.

On the 10th day after C-section, the patient was transferred to a superior hospital for inferior vena cava filter implantation and subsequent anticoagulant and thrombolytic therapy. On the 30th day after C-section, a CT scan revealed that the right OVT had disappeared.

\section{Discussion and conclusions}

In this case, we reported that right ovarian vein infectious thrombophlebitis occurred in a patient with foetal Vein of Galen malformation and abdominal incision haematoma after $\mathrm{C}$-section. Because of the low incidence of SPT, it is easily ignored by clinicians. This patient had a high fever and abnormal blood examination findings after $\mathrm{C}$-section. Anti-inflammatory treatment was not effective after 1 week. She underwent a second surgery for the removal of the abdominal wall incision haematoma to control the condition. It remains to be determined whether the haematoma was related to right ovarian infectious thromboembolic phlebitis. Wang et al. [4] concluded that venous thromboembolism (VTE) has been 

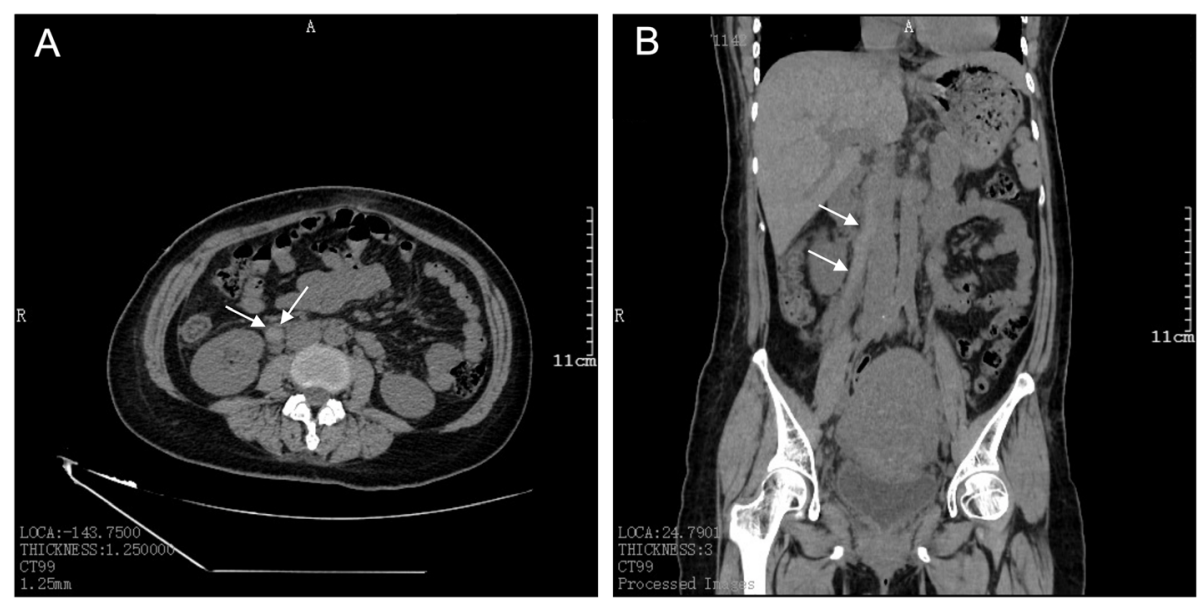

Fig. $1 \mathrm{CT}$ image showing right ovarian vein thrombosis. A Superior-inferior view. B Anterior-posterior view

considerably underestimated in Asia. Limited data exist on the incidence of VTE in the current literature.

An important feature of SPT is the simultaneous presence of bacterial infections and venous thrombosis [5]. The affected vein is characterized by phlebitis. The patient has severe fever or high fever, and a white blood cell rise is common in puerperal infections in pelvic infectious thrombophlebitis. SPT has dangerous clinical manifestations. In addition to pelvic infections, there can also be severe symptoms of high fever and poisoning. If

\begin{tabular}{|c|c|}
\hline $\begin{array}{l}\text { Day of delivery } \\
\text { (C-section) }\end{array}$ & $\begin{array}{l}\text { - } 35 \text {-year-old G3P2; } 41 \text { weeks; fetal vein of Galen malformation } \\
\text { - } 4600 \mathrm{~g} \text { male infant; APGAR } 10 / 10 / 10 \\
\text { - } 350 \mathrm{ml} \text { intraoperative blood loss }\end{array}$ \\
\hline $\begin{array}{l}\text { Post C-section } \\
\text { Day } 1\end{array}$ & $\begin{array}{l}\text { - wound painful but bearable } \\
\text { - WBC } 10.20 \times 10^{9} / \mathrm{L} \text {; hemoglobin } 97 \mathrm{~g} / \mathrm{L} \text {; platelet count } 79 \times 10^{9} / \mathrm{L}\end{array}$ \\
\hline $\begin{array}{l}\text { Post C-section } \\
\text { Day } 2\end{array}$ & $\begin{array}{l}\text { - } \text { aggravated pain } \\
\text { - palpable mass detected } \\
\text { - WBC } 11.32 \times 10^{9} / \mathrm{L} \text {; hemoglobin } 88 \mathrm{~g} / \mathrm{L} \text {; platelet count } 85 \times 10^{9} / \mathrm{L}\end{array}$ \\
\hline $\begin{array}{l}\text { Post C-section Day } 3 \\
\text { (Secondary surgery day) }\end{array}$ & $\begin{array}{l}\text { - body temperature } 38.2^{\circ} \mathrm{C} \\
\text { - } 43 \times 32 \times 10 \mathrm{~mm} \text { abdominal wall incision hematoma } \\
\text { - } \text { WBC } 9.05 \times 10^{9} / \mathrm{L} \text {; hemoglobin } 83 \mathrm{~g} / \mathrm{L} \text {; platelet count } 88 \times 10^{9} / \mathrm{L}\end{array}$ \\
\hline $\begin{array}{l}\text { Post secondary } \\
\text { surgery Day } 1\end{array}$ & $\begin{array}{l}\text { - body temperature } 39.5^{\circ} \mathrm{C} \\
\text { - hemoglobin } 89 \mathrm{~g} / \mathrm{L} \text {; platelet count } 108 \times 10 \% / \mathrm{L} \\
\text { - anti-inflammatory treatment }\end{array}$ \\
\hline $\begin{array}{l}\text { Post secondary } \\
\text { surgery Day } 2\end{array}$ & $\begin{array}{l}\text { - body temperature } 38.6^{\circ} \mathrm{C} \\
\text { - hemoglobin } 83 \mathrm{~g} / \mathrm{L} \text {; platelet count } 138 \times 10^{9} / \mathrm{L} \\
\text { - } \text { anti-inflammatory treatment }\end{array}$ \\
\hline $\begin{array}{c}\text { Post C-section Day } 7 \\
\text { (Post secondary } \\
\text { surgery Day 4) }\end{array}$ & $\begin{array}{l}\text { - body temperature } 37.2^{\circ} \mathrm{C} \\
\text { - hemoglobin } 84 \mathrm{~g} / \mathrm{L} \text {; platelet count } 167 \times 10^{9} / \mathrm{L} \\
\text { - } \text { fibrinogen } 2.24 \mathrm{~g} / \mathrm{L} \text {; D-dimer } 6.48 \mathrm{mg} / \mathrm{L} \\
\text { - } 1 \times 15 \mathrm{~cm} \text { right OVT confirmed by CT scan } \\
\text { - } \text { anti-inflammatory; anticoagulant; thrombolytic; inferior vena cava filter }\end{array}$ \\
\hline $\begin{array}{c}\text { Post C-section } \\
\text { Day } 30\end{array}$ & - Out-patient follow-up: OVT disappeared \\
\hline
\end{tabular}

Fig. 2 Timeline of events and findings. WBC: white blood cell; OVT: ovarian vein thrombophlebitis 
the infected thrombus breaks off, it can lead to lung abscesses and abscesses in other parts of the body.

Slow blood flow, damaged inner wall of the vein, and blood hypercoagulation are three major factors that increase thrombotic inflammation. When the infection is combined, the bacterial decomposition of heparinase decomposes heparin to promote coagulation. Pelvic venous thrombosis and bacterial infection are two essential factors for SPT [6]. However, the sequence and causal relationship between the two are still unknown. In a damaged venous wall, in the hypercoagulate state of postpartum blood, an infectious thrombosis is formed [7].

The dimer is produced by pyrolysis of plasminogen by plasmin. It can reflect the degree of fibrinolysis of the early activation of the coagulation reaction, and it is a specific marker of activation of the coagulation and fibrinolysis system [8]. Regular inspection of D-dimer content may be an important method for early elimination of thrombotic diseases [9]. D-dimer levels > $500 \mu \mathrm{g} / \mathrm{L}$ are the diagnostic criteria, with a sensitivity of $96.8 \%$ and a specificity of only $35.2 \%$ [10]. Therefore, this method cannot be used to diagnose thrombosis except for in certain diseases.

In view of the lack of precise laboratory examination methods, the diagnosis of SPT has been challenged. After physical examination, the patient usually has no toxic reaction. The lower abdomen may have tenderness on palpation, and occasionally, a cord or sausage-like abdominal tenderness may be recognized [11]. This is the most diagnostic finding in an abdominal examination, but it is rare. In less than one-third of cases, leukocytosis is moderate, and blood cultures are positive. In this case, although the patient's clinical condition did not change, the analysis parameters of inflammation improved after the third antibiotic treatment.

Although the incidence of VTE in Asian populations is lower than that in Western countries, the overall burden of VTE in Asia has been greatly underestimated [4]. Factors that can explain the lower prevalence of VTE in Asian populations relative to Western populations may include the limited availability of Asian epidemiological data, ethnic differences in genetic susceptibility to VTE, low awareness of thrombotic diseases in diagnosis, and fewer Asian patients with symptomatic VTE [12]. Generally, the clinical evaluation, diagnostic tests and treatment precautions of VTE between Asian and Western populations are the same. Management of VTE is based on balancing the benefits of treatment with the risk of bleeding. For Asian populations, this is a particularly important consideration because of the increased risk of intracranial haemorrhage caused by the use of vitamin $\mathrm{K}$ antagonists [13]. In major phase 3 clinical trials that include Asian populations, non-vitamin $\mathrm{K}$ antagonist oral anticoagulants (NOACs) have shown advantages over current treatment modalities in terms of bleeding outcomes [14]. Although the management of VTE has progressed, the management data of the incidence, prevalence, recurrence rate, risk factors and bleeding complications in the Asian population are still limited, and awareness needs to be improved. The decision to manage VTE is based on a balance between the benefits of treatment and the risk of bleeding. This is a particularly important consideration for the Asian population because Asians tend to have increased bleeding, especially intracranial haemorrhage [15]. Considering this risk, it is important to diagnose the disease in a timely and accurate manner and safely exclude the disease when it does not exist.

The case presented here illustrates the need to consider the potential relationship between abdominal incision haematoma and ovarian vein thrombophlebitis. Although progress has been made in the management of venous thromboembolism on a global scale, more epidemiological data are still needed, including first incidence, prevalence, recurrence and risk factors and management of bleeding complications in Asian populations.

\section{Abbreviations}

SPT: Septic pelvic thrombophlebitis; PVT: Pelvic venous thrombosis; VTE: Venous thromboembolism; PT: Pelvic thrombophlebitis; OVT: Ovarian vein thrombosis; DSPT: Deep septic pelvic thrombophlebitis; NOACs: Nonvitamin $\mathrm{K}$ antagonist oral anticoagulants

\section{Acknowledgements}

Not applicable.

\section{Authors' contributions}

QS and DSG collected data and drafted the manuscript. YH and YZ analyzed and interpreted the data. $J Y, X Y$ and $Y X$ contributed to the design of the study and the revision of the manuscript. ZY (Yuquan Zhang) reviewed and approved the final manuscript. All authors were involved in the care of the patient, and all authors read and approved the final manuscript.

\section{Funding}

This work was supported by National Natural Science Foundation of China (No. 81771527) for the article processing charge.

Availability of data and materials

All data are available in the manuscript.

\section{Declarations}

Ethics approval and consent to participate

All procedures were approved by the ethics committee of Affiliated hospital of Nantong university. Written informed consent was obtained by the patient presented.

\section{Consent for publication}

As above, written informed consent for publication was obtained by the patient. Written informed consent was obtained from the patient for publication of this case report and any accompanying images. A copy of the written consent is available for review by the Editor of this journal.

Competing interests

The authors declare that they have no competing interests. 


\section{Author details}

'Department of Obstetrics and Gynecology, Affiliated Hospital of Nantong University, Nantong, People's Republic of China. ${ }^{2}$ Affiliated Maternity and Child Health Care Hospital of Nantong University, Nantong, China.

Received: 30 March 2021 Accepted: 16 July 2021

Published online: 17 August 2021

\section{References}

1. Brown CE, Stettler RW, Twickler D, Cunningham FG. Puerperalseptic pelvic thrombophlebitis: incidence and response toheparin therapy. Am J Obstet Gynecol. 1999;181(01):143-14.

2. Parino E, Mulinaris E, Saccomano E, Gallo JC, Kohan G. Postpartum ovarian vein thrombophlebitis with staphylococcal bacteremia. Case Rep Infect Dis. 2015:2015:589436.

3. Roepke RML, de Campos FPF, Lovisolo SM, Santos EHS. Septic pelvic thrombophlebitis of unknown origin: an ever threatening entity. Autops Case Rep. 2014;4(3):39-46.

4. Wang KL, Yap ES, Goto S, Zhang S, Siu CW, Chiang CE. The diagnosis and treatment of venous thromboembolism in asian patients. Thromb J. 2018: 16:4.

5. DeNoble AE, Heine RP, Dotters-Katz SK. Chorioamnionitis and infectious complications after vaginal delivery. Am J Perinatol. 2019;36(14):1437-41.

6. Dotters-Katz SK, Smid MC, Grace MR, Thompson JL, Heine RP, Manuck T. Risk factors for postpartum septic pelvic thrombophlebitis: a multicenter cohort. Am J Perinatol. 2017;34(11):1148-51.

7. Wang J, Hu B, Li T, Miao J, Zhang W, Chen S, et al. The EGFR-rearranged adenocarcinoma is associated with a high rate of venous thromboembolism. Ann Transl Med. 2019;7(23):724.

8. Liederman Z, Chan N, Bhagirath V. Current challenges in diagnosis of venous thromboembolism. J Clin Med. 2020;9(11):E3509.

9. Yokomichi ALY, Rodrigues VDC, Moroz A, Bertanha M, Ribeiro SJL, Deffune $\mathrm{E}$, et al. Detection of factor VIII and D-dimer biomarkers for venous thromboembolism diagnosis using electrochemistry immunosensor. Talanta. 2020;219:121241

10. Chopard R, Albertsen IE, Piazza G. Diagnosis and treatment of lower extremity venous thromboembolism: a review. JAMA. 2020;324(17):1765-76.

11. Yamamoto S, Okamoto K, Okugawa S, Moriya K. Fusobacterium necrophorum septic pelvic thrombophlebitis after intrauterine device insertion. Int J Gynaecol Obstet. 2019;145(1):122-3.

12. Chen JS, Hung CY, Chang H, Liu CT, Chen YY, Lu CH, et al. Venous thromboembolism in Asian patients with pancreatic Cancer following palliative chemotherapy: low incidence but a negative prognosticator for those with early onset. Cancers (Basel). 2018;10(12):501.

13. Zhang $X$, Xie $Y$, Wang $H$, Yang D, Jiang T, Yuan $K$, et al. Symptomatic intracranial hemorrhage after mechanical Thrombectomy in Chinese ischemic stroke patients: the ASIAN score. Stroke. 2020;51(9):2690-6.

14. Almutairi AR, Zhou L, Gellad WF, Lee JK, Slack MK, Martin JR, et al. Effectiveness and Safety of Non-vitamin K Antagonist Oral Anticoagulants for Atrial Fibrillation and Venous Thromboembolism: A Systematic Review and Meta-analyses. Clin Ther. 2017;39(7):1456-1478.e36.

15. Hoshino T, Uchiyama S, Wong LKS, Kitagawa K, Charles H, Labreuche J, et al. Five-Year Prognosis After TIA or Minor Ischemic Stroke in Asian and NonAsian Populations. Neurology. 2021;96(1):e54-e66.

\section{Publisher's Note}

Springer Nature remains neutral with regard to jurisdictional claims in published maps and institutional affiliations.

Ready to submit your research? Choose BMC and benefit from:
- fast, convenient online submission
- thorough peer review by experienced researchers in your field
- rapid publication on acceptance
- support for research data, including large and complex data types
- gold Open Access which fosters wider collaboration and increased citations
- maximum visibility for your research: over 100M website views per year
At BMC, research is always in progress.
Learn more biomedcentral.com/submissions

